Original Research Article

\title{
Evaluation of pharmacological and toxicological studies of an ayurvedic medicine Rasaraj Ras on biological system of the male Sprague-Dawley rats
}

\author{
Ferdousi Akter, Md. Mamun Sikder*, Shemonty Hasan, Israt Jabin Emu, Massnoon Ali, \\ Manoth Kumer Biswas, Nilay Saha, M. S. K. Choudhuri
}

\begin{abstract}
Department of Pharmacy, Jahangirnagar University, Savar, Dhaka-1342, Bangladesh

Received: 09 September 2016 Accepted: 12 October 2016

*Correspondence to:

Dr. Md. Mamun Sikder,

Email: shikder1753@gmail.com

Copyright: (C) the author(s), publisher and licensee Medip Academy. This is an openaccess article distributed under the terms of the Creative Commons Attribution NonCommercial License, which permits unrestricted noncommercial use, distribution, and reproduction in any medium, provided the original work is properly cited.
\end{abstract}

\begin{abstract}
Background: In this study, the pharmacological and toxicological effects along with possible side effects of the classical ayurvedic formulation Rasaraj Ras (RR) which is used as a traditional medicine in the treatment of hemiplegia in the rural population were evaluated.

Methods: During this study, various experiments on body growth rate, organbody weight ratio and tissue hydration indices were performed to evaluate its efficacy and toxicity. To find out the toxicological characteristic of RR, it was administered chronically to the male Sprague-Dawley rats at a dose of 40 $\mathrm{mg} / \mathrm{kg}$. After 28 days chronic administration of the RR preparation the following toxicological changes were noted.

Results: All throughout the experimental period the RR treated animals were always maintaining negligible changes in body weight, but all throughout the experimental period no statistically significant increase or decrease was noted. There is a statistically significant decrease in the relative percent weight of the male rat heart. There is a statistically highly significant decrease in the absolute weight of the male rat liver. There is a statistically highly significant decrease in the relative percent weight of the male rat liver. There is a statistically significant decrease in the relative percent weight of the male rat kidney. In the tissue hydration index determination, no significant changes were noted in case of any organ.
\end{abstract}

Conclusions: As RR decreases abnormally weight of several organs in body of treated rats, so it should not be administered chronically at a higher dose.

Keywords: Absolute weight, Organ percent weight, Organ water content Pharmacological, Rasaraj Ras, Toxicological

\section{INTRODUCTION}

Ayurvedic medicines have reputation as decent and effective remedies for a number of diseases. ${ }^{1}$ Currently, the World Health Organization (WHO) has officially recognized and recommended large-scale use of herbal (Unani and Ayurvedic) medicines, particularly in the developing countries, as an alternative system of medicine to deliver health care services at the primary health care level. ${ }^{2}$ According to WHO, an estimated 1.5 billion people of the world are now getting treatment with these medicines. ${ }^{3,4}$ They have a good safety profile also. ${ }^{5}$

Rasaraj Ras (RR) an Ayurvedic preparation used as a traditional medicine in the treatment of hemiplegia in the rural populatio. ${ }^{6,7}$
Rasaraj Rasa is included in the Bangladesh National Formulary of Ayurvedic Medicine 1992 (Approved by the Government of Bangladesh vide Ministry of Health and Family Welfare Memo No. Health-1/Unani2/89/(Part-1) 116 dated 3-6-1991).

\section{METHODS}

\section{Drugs, chemicals and reagents}

For the toxicological study, Rasaraj Ras (RR) was collected from Sri Kundeswari Aushadhalaya Limited, Chittagong. Ketamine injection was purchased from ACI Limited, Bangladesh. All other reagents, assay kits and chemicals used in this work were purchased from Human GmbH, Wiesbaden, Germany. 


\section{Experimental animals}

Six to eight-week old male Sprague-Dawley rats bred and maintained at the animal house of the Department of Pharmacy, Jahangirnagar University, were used in the pharmacological experiment. These animals were apparently healthy and weighed 60-70 g. The animals were housed in a well-ventilated clean experimental animal house under constant environmental and adequate nutritional conditions throughout the period of the experiment. They were fed with rat chow prepared according to the formula developed at Bangladesh Council of Scientific and Industrial Research (BCSIR). Water was provided ad libitum and the animals maintained at $12 \mathrm{~h}$ day and $12 \mathrm{~h}$ night cycle. All experiments on rats were carried out in absolute compliance with the ethical guide for care and use of laboratory animals approved by Ethical Review Committee, Faculty of Life Sciences, Department of Pharmacy, Jahangirnagar University.

\section{Table 1: Name of the ingredients/herbs used in the preparation of Rasaraja Rasa.}

\begin{tabular}{|l|}
\hline Ingredients botanical/English name amounts \\
\hline Parada Purified and processed Mercury $48 \mathrm{~g}$ \\
\hline Abhrakasatva Purified and processed Silica $12 \mathrm{~g}$ \\
\hline Swarna Bhasma Gold Bhasma $12 \mathrm{~g}$ \\
\hline Loha Bhasma Iron Bhasma $6 \mathrm{~g}$ \\
\hline Rajata Bhasma Silver Bhasma $6 \mathrm{~g}$ \\
\hline Vanga Bhasma Tin Bhasma $6 \mathrm{~g}$ \\
\hline Vajigandha (Root) Withania somnifera $6 \mathrm{~g}$ \\
\hline Lavanga (Flower) Syzigium aromaticum $6 \mathrm{~g}$ \\
\hline Jatikosha (Ar.) Myristica fragrans $6 \mathrm{~g}$ \\
\hline Ksheerakakoli (Root) Fritilerria roylei $6 \mathrm{~g}$ \\
\hline $\begin{array}{l}\text { Kakamachirasa (Juice) Solanum nigrum Quantity } \\
\text { sufficient }\end{array}$ \\
\hline
\end{tabular}

\section{Experimental design}

\section{Acute pharmacological study}

The acute oral pharmacological test was performed following the guidelines of Organization for Economic Co-operation and Development (OECD) for testing of chemicals with minor modifications (OECD Guideline $425){ }^{8}$ Sixteen male mice (30-40 g body weight) were divided into four groups of four animals each.

Different doses $(50 \mathrm{ml} / \mathrm{kg}, 60 \mathrm{ml} / \mathrm{kg}, 70 \mathrm{ml} / \mathrm{kg}$ and 80 $\mathrm{ml} / \mathrm{kg}$ ) of experimental drug Rasaraj Ras (RR) were administered by stomach tube. The dose was divided into two fractions and given within 12 hours. Then all the experimental animals were observed for mortality and clinical signs of toxicity (general behavior, respiratory pattern, cardiovascular signs, motor activities, reflexes and changes in skin and fur texture) at 1,2,3 and 4 hours and thereafter once a day for the next three days following RR administration.

\section{Chronic pharmacological studies}

Prior to the experiment, rats were randomly divided into 2 groups of 8 animals each. One group was treated with Rasaraj Ras (RR) and another was used as a control. The control animals were administered with distilled water only as per the same volume as the drug treated group for 28 days. For all the pharmacological studies the drugs were administered per oral route at a dose of $40 \mathrm{mg} / \mathrm{Kg}$ body weight. ${ }^{9}$ After acclimatization, Ayurvedic medicinal preparation was administered to the rats by intra-gastric syringe between the 10 am to 12 am daily throughout the study period. All experiments on rats were carried out in absolute compliance with the ethical guide for care and use of laboratory animals. The experiment animals were marked carefully on the tail which helped to identify a particular animal. By using identification mark, responses were noted separately for a particular period prior to and after the administration. ${ }^{10}$

\section{Growth analysis}

Careful monitoring of body weights of rats of both sexes was performed throughout the 28 days drug administration period. Body weights were recorded at regular intervals (2-3 days) until the treatment period was completed. All rats were kept under close observation throughout the experimental period. An equal numbers of animals of the same species were also maintained as the Control group and these were also kept under close observations. Statistical analysis of the initial and final growth rates was performed. The growth rate, expressed as percent increment in the body weight. The growth rate of the treatment group was compared with that of the Control group.

\section{Body weight: Organ weight ratio analysis}

At the end of the 28 day treatment period, the animals were fasted for 18 hours and also twenty-four hours after the last administration. Ketamine $(500 \mathrm{mg} / \mathrm{kg}$ i.p. $)$ was administered for the purpose of anesthesia. ${ }^{11}$ Rats of both Rasaraj Ras (RR) and Control groups were sacrificed after the completion of the 28-day period and examined macroscopically for external lesions. Necropsy was performed to examine gross pathological lesions of various internal organs.

Specific organs of interest were then detached and preserved in $13 \%$ formalin and sent for the evaluation of histological anomalies, if any. The tissues thus subjected to histopathological evaluation are: Heart, kidney, lungs, liver, spleen, thymus, stomach, caecum, pancreas, adrenal glands, urinary bladder, reproductive organs, which include testis, seminal vesicles, prostate gland and epididymis in case of males and ovaries, fallopian tube and uterus in case of females.

Organs like heart, lungs, liver and spleen, portions of these tissues were excised and preserved for histological 
examination. The remaining portions were dried for determination of water content.

Relative weight of organ $=\frac{\mathrm{AOW}}{\mathrm{BW}} \times 100$

$\mathrm{AOW}=$ Absolute organ weight; $\mathrm{BW}=$ body weight

Water content in tissue $=\frac{\mathrm{OW} 1-\mathrm{OD}}{\mathrm{OW} 1-\mathrm{OF}} \times 100$

$\mathrm{OW}_{1}=$ organ wet weight $\mathrm{OD}=$ organ dry weight; $\mathrm{OF}=$ organ foil weight

\section{Statistical analysis}

The data were analysed using independent sample t-test with the help of SPSS (Statistical Package for Social Science) Statistics 11.5 package (SPSS Inc., Chicago Ill). All values are expressed as mean \pm SEM (Standard Error Mean) and $\mathrm{p}^{*} \leq 0.05, \mathrm{p}^{* *} \leq 0.01, \mathrm{p}^{* * *} \leq 0.001$ was taken as the level of significant.

\section{RESULTS}

\section{Acute pharmacological study}

The Rasaraj Ras (RR) administered up to a high dose of $80 \mathrm{ml} / \mathrm{kg}$ produced no mortality. Thus the $\mathrm{LD}_{50}$ value was found to be greater than $80 \mathrm{ml} / \mathrm{kg}$ body weight. According to the OECD test guideline 425 when there is information in support of low or non-toxicity and immortality nature of the test material, then the limit test at the highest starting dose level ( $80 \mathrm{ml} / \mathrm{kg}$ body weight) was conducted. There were no mortality and toxicity signs observed at $80 \mathrm{ml} / \mathrm{kg}$ body weight. Therefore, it can be concluded that RR when administered at single dose is non-toxic and can be used safely in oral formulations.

\section{Effect of RR on overall body weight}

The total treatment period was of 28 days. All throughout the experimental period the RR treated animals were always maintaining negligible $(0.55 \%$ gain $(\mathrm{p}=0.929)-$ $0.80 \%$ loss $(\mathrm{p}=0.873)$ ) changes in body weight, but all throughout the experimental period no statistically significant increase or decrease was noted.

\section{Effect of RR on organ pharmacological study}

In absolute weight determination, results show that There is a statistically highly significant $(\mathrm{p}=0.007)$ decrease in the absolute weight of the male rat liver [19.94\% decrease]. In relative weight determination results show, There is a statistically significant $(\mathrm{p}=0.025)$ decrease in the relative percent weight of the male rat heart $[8.07 \%$ decrease]. There is a statistically highly significant $(\mathrm{p}=0.008)$ decrease in the relative percent weight of the male rat liver [19.62\% decrease]. There is a statistically significant $(\mathrm{p}=0.056)$ decrease in the relative percent weight of the male rat kidney [9.11\% decrease].

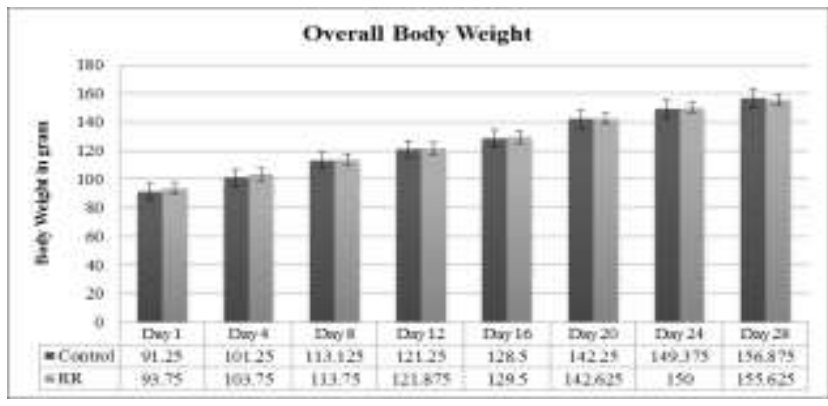

Independent sample t-test was performed to analyse this weight variation in different days. All values are expressed as mean \pm SEM and $\mathrm{p}^{*} \leq 0.05, \mathrm{p}^{* *} \leq 0.01, \mathrm{p}^{* * *} \leq 0.001$ were taken as the level of significant.

Figure 1: The effect Rasaraj Ras $(40 \mathrm{mg} / \mathrm{kg})$ on the body weights (g) of Sprague-Dawley rats with the time of treatment.

\section{Chronic growth study}

Effect of RR on tissue hydration index

In the tissue hydration index determination, no significant changes were noted in case of any organ.

Table 2: The effect of Rasaraj Ras (RR) $(40 \mathrm{mg} / \mathrm{kg})$ on the absolute organ weights of male rats.

\begin{tabular}{|ll|lll|}
\hline Parameters & Control & RR & p value & \% increase/decrease \\
\hline Heart & $0.4646 \pm 0.02222$ & $0.4244 \pm 0.01552$ & 0.16 & $\downarrow 8.65$ \\
\hline Lung & $0.8841 \pm 0.03987$ & $0.9104 \pm 0.03089$ & 0.61 & $\uparrow 2.97$ \\
\hline Liver & $6.7825 \pm 0.36095$ & $5.4299 \pm 0.22651$ & $0.007 * *$ & $\downarrow 19.94$ \\
\hline Kidney & $0.5599 \pm 0.02303$ & $0.507 \pm 0.01553$ & 0.078 & $\downarrow 9.45$ \\
\hline Spleen & $0.7074 \pm 0.04301$ & $0.6337 \pm 0.09935$ & 0.512 & $\downarrow 10.42$ \\
\hline Testis & $1.0759 \pm 0.03306$ & $1.0458 \pm 0.01002$ & 0.407 & $\downarrow 2.80$ \\
\hline
\end{tabular}

$\uparrow:$ increase; $\downarrow$ : decrease; $\mathrm{p}^{*} \leq 0.05 ; \mathrm{p}^{* *} \leq 0.01 ; \mathrm{p}^{* * *} \leq 0.001$ 
Table 3: The effect of Rasaraj Ras (RR) $(40 \mathrm{mg} / \mathrm{kg})$ on the relative organ weights of male rats.

\begin{tabular}{|ll|lll|}
\hline Parameters & Control & RR & p value & \%increase/decrease \\
\hline Heart & $0.2963 \pm 0.00774$ & $0.2724 \pm 0.00555$ & $0.025^{*}$ & $\downarrow 8.066$ \\
\hline Lung & $0.564 \pm 0.01312$ & $0.5902 \pm 0.03325$ & 0.476 & $\uparrow 4.65$ \\
\hline Liver & $4.3542 \pm 0.22992$ & $3.4999 \pm 0.15534$ & $0.008^{* *}$ & $\downarrow 19.62$ \\
\hline Kidney & $0.3589 \pm 0.01323$ & $0.3262 \pm 0.00834$ & $0.05^{*}$ & $\downarrow 9.11$ \\
\hline Spleen & $0.4619 \pm 0.02116$ & $0.4094 \pm 0.06939$ & 0.489 & $\downarrow 11.37$ \\
\hline Thymus & $0.1466 \pm 0.01648$ & $0.1265 \pm 0.0295$ & 0.538 & $\downarrow 13.71$ \\
\hline Testis & $0.6897 \pm 0.01931$ & $0.6749 \pm 0.01643$ & 0.568 & $\downarrow 2.15$ \\
\hline
\end{tabular}

$\uparrow:$ increase; $\downarrow$ : decrease; $\mathrm{p}^{*} \leq 0.05 ; \mathrm{p}^{* *} \leq 0.01 ; \mathrm{p}^{* * *} \leq 0.001$

Table 4: The effect of Rasaraj Ras $(R R)(40 \mathrm{mg} / \mathrm{kg})$ on various tissue hydration indices of male rats.

\begin{tabular}{|ll|lll|}
\hline Parameters & Control & RR & p value & \% increase/decrease \\
\hline Heart & $76.7788 \pm 1.77558$ & $74.5269 \pm 2.81526$ & 0.525 & $\downarrow 2.93$ \\
\hline Lung & $73.9187 \pm 6.85189$ & $73.9765 \pm 4.46345$ & 0.994 & $\uparrow 0.078$ \\
\hline Liver & $76.0269 \pm 0.32347$ & $75.0743 \pm 1.21306$ & 0.461 & $\downarrow 1.25$ \\
\hline Kidney & $77.6486 \pm 2.33869$ & $80.5775 \pm 1.84735$ & 0.342 & $\downarrow 3.77$ \\
\hline Spleen & $76.8223 \pm 1.26437$ & $70.1826 \pm 3.86954$ & 0.148 & $\downarrow 8.64$ \\
\hline Testis & $86.5863 \pm 0.56317$ & $119.74 \pm 33.96021$ & 0.346 & $\downarrow 38.29$ \\
\hline
\end{tabular}

$\uparrow:$ increase; $\downarrow$ : decrease; $\mathrm{p}^{*} \leq 0.05 ; \mathrm{p}^{* *} \leq 0.01 ; \mathrm{p}^{* * *} \leq 0.001$

\section{DISCUSSION}

The administration of herbal preparations without any standard dosage along with insufficient scientific studies on their safety profile has raised concerns on their toxicity. ${ }^{12}$ Change in body weight is a sign of impairment in the normal functioning of the body. All throughout the experimental period the RR treated animals were always maintaining negligible changes in body weight, but all throughout the experimental period no statistically significant increase or decrease was noted. Rapid body weight change may be due to feed and/or water consumption, disease, dental maladies, or specific toxic effects. $^{13}$

Relative organ weight (ROW) may serve as a sign of pathological and physiological status in man and animals. Toxic substances induce abnormal metabolic reactions that affect primary organs (e.g. heart, liver, spleen, kidney and lung). ${ }^{14}$ Change in organ weight is a symbol of impairment in the normal body functioning. Organbody weight ratio may indicate organ swelling, atrophy or hypertrophy. ${ }^{15}$

Drug-induced alterations in blood pressure, heart rate or cardiac conduction in animal studies may have implications for safety of a novel drug, even if they are devoid of any morphological correlate. ${ }^{16}$ In this study we found, heart weight decrease significantly to the Rasaraj Ras treated rats. Reduced heart weight has been reported in toxicity studies in which dogs and rats were treated with high doses of angiotensin-converting enzyme (ACE) inhibitors. Reductions in total ventricular weight, left ventricular weight and right ventricular weight normalized for body weight and reductions in mean arterial blood pressure were also reported in SpragueDawley rats receiving continuous infusions of the synthetic atriopeptin III. ${ }^{17}$ It was postulated that the reductions in heart weight were the result of the effect of atriopeptin III on fluid volume by an enhanced passage of fluid from the intramuscular to extra muscular compartment, or dieresis with subsequent alterations to cardiac workload.

Dose-related increases in liver weight are commonly observed in repeat-dose toxicity studies performed in rodents, although in dog or other large animal studies, the individual variations and the small numbers of animals used makes assessment of liver weight changes less certain. The causes of liver weight changes are diverse. One documented aged-related change in both humans and laboratory rodents is a decline in liver volume. ${ }^{18}$ Here we found significantly decrease of liver weight to the Rasaraj Ras treated rats.

Renal weight in laboratory animals appears not to show a close relationship with body weight. Here we found significantly decrease of kidney weight to the Rasaraj Ras treated rats. However in humans, renal weight appears to decrease with advancing age. This has been linked to thickening of the intra-renal vascular intima, sclerosis of the glomeruli, infiltration by chronic inflammatory cells 
and stromal fibrosis associated with altered renal tubular function. These changes may modify the pharma-cokinetics and pharmacodynamics of administered drugs. ${ }^{19}$

Several physiological disorders can be caused by dehydration. It comprises from $75 \%$ body weight in infants to $55 \%$ in elder people and it is essential for maintaining cellular homeostasis. In our study, we found that RR did not cause any significant change in water content of any organ of our body. It can be suggested that this drug has no impact on maintaining cellular hemostasis.

\section{CONCLUSION}

From the above experiment it can be concluded that RR should not be administered chronically at a higher dose as it decrease weight of heart, liver, kidney. Further studies should be done by reducing the administered dose.

\section{ACKNOWLEDGEMENT}

The authors are thankful to Focused Research on Ayurvedic Medicine and Education (F.R.A.M.E) Laboratory, Department of Pharmacy and all faculty members and the technical staffs of the Department of Pharmacy, Jahangirnagar University for their kind cooperation. We would express our special thanks to $\mathrm{Mr}$. Shafiqul Islam for ensuring a constant supply of animals followed by proper maintenance and care of these animals during all throughout the experimental period.

\section{Funding: No funding sources}

Conflict of interest: None declared

Ethical approval: The study was approved by the Institutional Ethics Committee

\section{REFERENCES}

1. WHO. Regional Office for the Western Pacific Seminar on the Use of Medicinal Plants in Health Care, Final Report, Tokyo, Japan: 1977, pp. 13-7.

2. WHO. WHO Launches the First Global Strategy on Traditional and Alternative Medicine, Press Release, WHO / 38: 2002.

3. WHO. Consultation Meeting on Traditional Medicine and Modern Medicine: Harmonizing the Two Approaches. Geneva, World Health Organization, (document reference (WP) TM/ICP/TM/001/RB/98RS/99/GE/32(CHN), Geneva, Switzerland: 1999a.

4. WHO. Traditional, Complementary and Alternative Medicines and Therapies. Washington DC, WHO
Regional Office for the Americas/Pan American Health Organization (Working group OPS/OMS), Washington DC, USA: 1999b.

5. Ernst E. Pharmacoepidemiol Drug Saf. 2002;11(6):4556.

6. Anonymous. Bangladesh National Formulary of Ayurvedic Medicine 1992 (Approved by the Government of Bangladesh vide Ministry of Health and Family Welfare Memo No. Health-1/Unani-2/89/(Part1) 116 dated 3-6-1991). National Unani and Ayurvedic Formulary Committee Bangladesh Board of Unani and Ayurvedic Systems of Medicine, 38, Bangabandhu Avenue, Dhaka-1000. Second ed. 2011.

7. Anonymous, The Ayurvedic formulary of India, Part I. 151 edition New Delhi: Government of India, Ministry of health and family welfare, Department of health. 1978; pp. 249.

8. OECD Guideline (425) for the testing of chemicals, Guidance document on acute oral toxicity, Environmental Health and Safety Monograph Series on Testing and Assessment, 2000.

9. Gad SC. An Approach to the Design and Analysis of Screening Studies in Toxicology, Intl J Tox. 1988;7:(2):127-38.

10. Stevens KR, Gallo MA. Practical consideration in the conduct of chronic toxicity studies, Principles and Methods of Toxicology, 2nd edn. Chap. VIII, 1989.

11. Ringler $H$, Dabich L. Hematology and clinical biochemistry. In: The Laboratory Rat Biology and Disease [Baker HL ed].American College of Laboratory Animal Medicine Series Academic Press, 1979.

12. Saad B, Azaizeh H, Abu-Hijleh G, Said S. Evid. Based Complement. Alternat. Med. 2006;3:433-9.

13. Haschek WM, Rousseaux CG, Wallig MA. Haschek and Rousseaux's Handbook of Toxicologic Pathology 3rd revised ed., Chapter 6, Elsevier Science: pp. 154. 2013.

14. Dybing E, Doe J, Groten J, Kleiner J, Brien J. Food Chem Toxicol. 2002;42:237-82.

15. Amresh GR, Singh PN, Rao VC. J. Ethnopharmacol. 2008;116:454-60.

16. Haschek and Rousseaux's Handbook of Toxicologic Pathology. Ed W.M. Haschek, C.G. Rousseaux and M.A. Wallig. 3rd revised ed., Elsevier Science, 2013 ISBN 9780124157651. Chapter 7 pp. 271.

17. Spokas EG, Suleymanov OD, Bittner SE. Cardiovascular effects ofchronic high-dose atriopeptin III infusion in normotensive rats. Toxicology and Applied Pharmacology. 1987;91:305-14.

18. Schmucker DL. Age-related changes in liver structure and function: implications for disease. Experimental Gerontology. 2005;40: 650-9.

19. Muhlberg W, Piatt D. Age-dependent changes of the kidneys: pharmaco-logical implications. Gerontology. 1999;45:243-53.

Cite this article as: Akter F, Sikder MM, Hasan S, Imu IJ, Ali M, Biswas MK, et al. Evaluation of pharmacological and toxicological studies of an ayurvedic medicine Rasaraj Ras on biological system of the male Sprague-Dawley rats. Int J Basic Clin Pharmacol 2016;5:2371-5. 